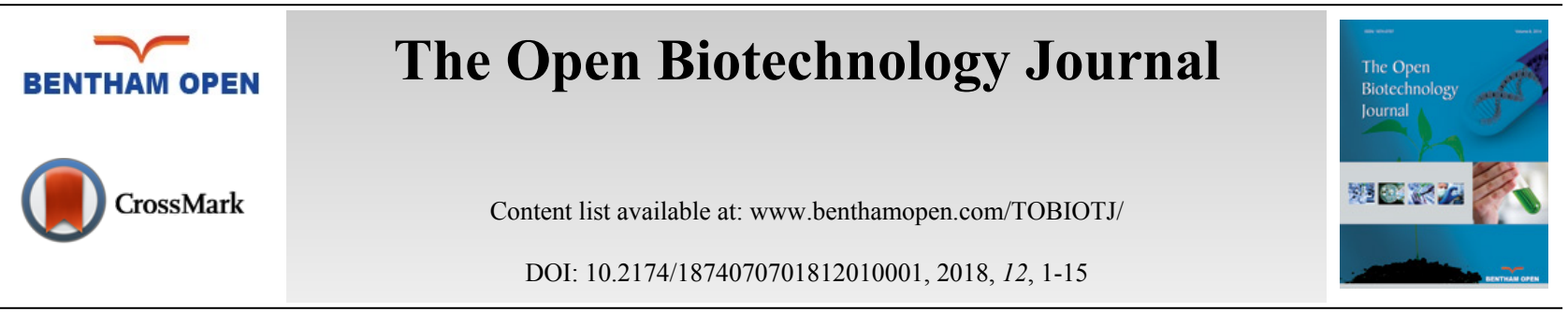

RESEARCH ARTICLE

\title{
Chemical Profiling and Antimicrobial Properties of Phyto-Active Extracts from Terminalia glaucescens Stem Against Water Microbial Contaminants
}

\author{
Adeyemi Ojutalayo Adeeyo ${ }^{1,2, *}$, John Odiyo ${ }^{2}$ and Kehinde Odelade ${ }^{1}$ \\ ${ }^{I}$ Department of Pure and Applied Biology, Ladoke Akintola University of Technology, P.M.B 4000, Ogbomoso, Oyo \\ State, Nigeria \\ ${ }^{2}$ School of Environmental Sciences, University of Venda, Private Bag X5050, Thohoyandou 0950, South Africa
}

Received: October 25, 2017

Revised: January 17, 2018

Accepted: January 29, 2018

\begin{abstract}
:
Background:

The present study was designed to evaluate the phytochemicals of Terminalia glaucescens stem extracts and test their antimicrobial potency against water microbial contaminants reported to be multidrug resistant.
\end{abstract}

\section{Method:}

Dry stem powder was extracted with ethanol, ethyl acetate and chloroform. These fractions were then examined for antimicrobial activity by using disc diffusion assay against typical clinical bacteria and fungal isolates which have been reported as water contaminants. The microbial strains were exposed to five different concentrations of extracts: $500 \mathrm{mg} / \mathrm{ml}, 250 \mathrm{mg} / \mathrm{ml}, 100 \mathrm{mg} / \mathrm{ml}, 50$ $\mathrm{mg} / \mathrm{ml}$ and $25 \mathrm{mg} / \mathrm{ml}$.

\section{Result:}

It was observed in this study that increase in the concentration of extracts correlated with microbial growth inhibition. In-vitro phytochemical screening of plant extracts revealed the presence of alkaloid, flavonoid, saponin, terpenoid, steroid and anthraquinones. Ethanolic extract performs better than ethyl acetate and chloroform extracts, as it recorded the highest zone of inhibition of $20.5 \mathrm{~mm}$ against Streptococcus pneumoniae while ethyl acetate and chloroform recorded $17.50 \mathrm{~mm}$ each against Streptococcus pneumoniae and Bacillus cereus, respectively. Ethanolic extract also showed the highest antifungal activity against Trichoderma sp. and Aspergillus niger. The antibacterial and antifungal activities of active extracts were observed in the increasing order Ethanol $>$ Chloroform $\geq$ ethyl acetate with respect to the maximum zone of inhibition. Activity of crude extract from ethanol, when further compared with commercial antibiotics (Gentamicin, Streptomycin and Nystatin), was significantly higher.

\section{Conclusion:}

This plant crude extracts could therefore serve as potential source of new biocides with application in water research and other biotechnological fields.

Keywords: Antimicrobials, In-vitro, Phytochemical, Terminalia glaucescens, Chemical profiling, Contaminants.

\section{INTRODUCTION}

Fungi and bacteria are of veterinary and human significance. Bacillus cereus has been involved in foodborne intoxication [1]. Escherichia coli and Pseudomonas aeruginosa cause ailments like mastitis, abortions and upper

\footnotetext{
* Address correspondence to this author at the School of Environmental Sciences, University of Venda, Private Bag X5050, Thohoyandou 0950,
} South Africa; Tel: +27723030995; E-mail: firstrebby@gmail.com 
respiratory complications. Streptococcus spp is a pathogenic bacteria usually found in the intestines of birds [1, 2]. Fungi like Aspergillus niger, have been reported to cause lung diseases, aspergillosis and otomycosis. Aspergillus flavus is a livestock and human pathogen associated with aspergillosis of the lungs and sometimes causes corneal, otomycotic and naso-orbital infections. They produce significant quantity of aflatoxin [3, 4]. Candida albicans is reported to cause asthma [5], vaginitis and yeast mastitis. These sets of organisms have been described to be multi-drug resistant and established as recent contaminants of water bodies [6 - 10]. Research in recent years have revealed multidrug resistance in different bacterial species [6,8]. Some emerging fungal water contaminants have also been reported [7]. Some of these resistant microbial spp are currently being found in water bodies [9,10]. Reports exist to show the continuous isolation of pathogenic microorganisms especially, antibiotic resistant strains from water and wastewater. Sisti [11] and Sidhu [12], reported a high incidence of bacteria spp from influent and effluent of urban waste and water purification plants. In addition, bacteria spp isolated from sewage have also been found in fresh water and drinking water even after chlorination. Health and environmental implications of these organisms, necessitate a search for novel lead compounds that could be used against such microbes. The pitfalls of chemical coagulants and disinfectants in water such as alum and chlorine also necessitate studies to further develop biomaterials as green and low cost treatment alternative for global treatment and management amidst growing global water crises [5]. It is also incumbent to curb and treat this water contamination bearing in mind that the total water volume on earth cannot be increased. Interest in plants with antimicrobial properties has been revitalized as a consequence of antimicrobial resistance attributed to indiscriminate use of commercial drugs [13], undesirable side effects of synthetic antimicrobials with respect to the emergence of previously uncommon diseases [14, 15], limited effective life span and high cost of synthetic antimicrobials [16]. The efficacy of synthetic antimicrobial agents has been abridged due to the continuing emergence of drug resistant organisms and the adaptations by microbial pathogens to commonly used antimicrobials [17]. While hundreds of plant species had been tested for antimicrobial properties, the vast majority of plants remained unassessed [18 - 20]. In spite of the presence of numerous approaches to drug discovery, plants still remain the leading reservoir of natural medicines [21] and represent a starting point for antimicrobial compounds discovery [22].

Terminalia glaucescens is a key component of the plants used in the formulation of the "wonder cure" concoction used in the management of tuberculosis in Nigeria. The efficacy of the plant extract on Mycobacterium tuberculosis was established by Adeleye et al. [23]. Terminalia species are used as traditional medication in the treatment of dysentery, and also found use in the last stages of management of AIDS [24, 25]. It is anticipated that plant secondary metabolic extracts with target sites other than those used by antibiotics will be effective against drug resistant pathogens [26]. These extracts are of great importance to scientists working on infectious diseases because they signify a possible source of unique antibiotic prototypes [6, 16]. Approximately $80 \%$ of the populaces in developing nations use traditional medical specialties for their wellness and care [27]. The genus Terminalia is the second largest genus of the Combretaceae after Combretum, with about 200 species. These plants spread in tropical areas of the globe with the greatest genetic diversity in Southeast Asia [28]. Genus Terminalia gets its name from Latin terminus, as the leaves appear at the tips of the shoots [29]. Terminalia species range from shrubs to huge deciduous forest trees. Mostly they are very large trees reaching in height up to $75 \mathrm{~m}$ tall [30]. Terminalia spp are widely used in traditional medicine in a number of continents in the world for the treatment of diseases including, abdominal disorders, bacterial infections, colds, diarrhea, dysentery, sore throats, conjunctivitis, fever, heart diseases, hookworm, gastric ulcers, headaches, hypertension, jaundice, edema, pneumonia, leprosy, nosebleed, and skin diseases [31]. The fruits of both T. chebula and T. bellerica are vital constituents of "triphala", a popular Ayurvedic formulation that possesses several activities in the Indian traditional medicine [32]. T. chebula fruit possesses an amazing power of healing and is called the "King of Medicine" in Tibet as it is used for the treatment of various illnesses [33, 34]. The Bark of T. arjuna is used as cardioprotective and anti-hyperlipidemia in folklore treatment [35]. In Africa, T. mollis is used to treat gonorrhea, malaria, diarrhea, and HIV management, while T. brachystemma is used for the treatment of shistosomiasis and gastrointestinal complaints [36].

Phytochemicals, are often secondary metabolites existing in smaller amounts in higher plants which include terpenoids, tannins, alkaloids, steroids, flavonoids and many others [37]. Different studies and researchers have used different extraction procedures and investigated medicinal importance in several plants. Tom et al. [38] and others [39 42] have equally investigated the medicinal importance of different Terminalia spp using different extraction methods. A current expectation in this field of inquiry is the hunt for emerging plants and plant materials with novel biotechnological applications such as the application of Cola nitida and D. eriocarpum in water purification and nanoparticle synthesis as paint additives [43,44]. Table 1 consists of some biotechnological applications of plant extracts. 
Table 1. Phytobiotechnological application prospects of plant extracts.

\begin{tabular}{|c|c|c|}
\hline Application areas & Plant & Reference \\
\hline Bio-fertilizers & $\begin{array}{l}\text { Tea-seed (Camellia sp) } \\
\text { Ascophyllum nodusum }\end{array}$ & $\begin{array}{c}\text { Andresen and Cedergreen, 2010; Norrie and } \\
\text { Keathley, 2006. [70,71] }\end{array}$ \\
\hline Artificial insemination & $\begin{array}{c}\text { Curcurbita pepo } \\
\text { Khaya senegalensis }\end{array}$ & Yongabi, 2005 [72] \\
\hline Bio-shampoo & $\begin{array}{c}\text { Accacia concinna (Willd.) DC, Averrhoa bilimbi Linn. } \\
\text { and Tamarindus indica Linn.) }\end{array}$ & Rassami and Soonwera, 2013 [73] \\
\hline Drink flavours & Tetrapleura tetraptera & Korankye, 2010 [74] \\
\hline Food colourant & Tefashia $s p$ & Korankye, $2010[74]$ \\
\hline Fumigants & Syzygium aromaticum & Rahuman et al., 2011 [75] \\
\hline $\begin{array}{l}\text { Insect repellants, larvicides } \\
\text { insecticides and pesticides }\end{array}$ & Mesua ferra L, Tephrosia vogeli, Petivera alliacea. & $\begin{array}{c}\text { Olaitan and Abiodun, 2011; Singha et al., } 2011 \text { [76, } \\
\text { 77] }\end{array}$ \\
\hline Livestock ethno-therapy & $\begin{array}{c}\text { Carica papaya } \\
\text { Zingiber officinale }\end{array}$ & Yongabi, 2005 [72] \\
\hline $\begin{array}{c}\text { Nanoparticle production and paint } \\
\text { additives }\end{array}$ & Cola nitida & Lateef et al. 2015; Lateef and Adeeyo, $2015[43,46]$ \\
\hline Water purification & $\begin{array}{c}\text { Moringa oleifera, Jatropha curcas, Guar gum and } \\
\text { Dicerocaryum eriocarpum }\end{array}$ & $\begin{array}{c}\text { Pritchard et al., } 2009 \\
\text { Odiyo et al., } 2017[44,78]\end{array}$ \\
\hline
\end{tabular}

The present study reports the phytochemical screening and antimicrobial activities of Terminalia glaucescens extracts as potential biocide against emerging microbial water contaminants.

\section{MATERIALS AND METHODS}

\subsection{Materials}

The chemicals used were obtained from Sigma-Aldrich, Germany through Lab Trade Chemicals Limited Nigeria and are of Analytical grades. Filter papers were from Whatman, GE Healthcare companies, China. The bacterial strains were obtained from Ladoke Akintola Univerity of Technology (LAUTECH) Teaching Hospital, and Obafemi Awolowo Univeristy (OAU), Nigeria.

\subsection{Plant Sample}

Newly harvested Terminalia glaucescens were obtained from Oja Igbo market, Ogbomoso North local government, Ogbomoso, Oyo State, Nigeria. Plant samples were moved to the lab immediately in polyethylene bags for preparation in order to avoid the decomposition of bioactive compounds.

\subsection{Preparation of Samples}

The plant stems were carefully washed in order to get rid of contaminants and impurities and were, shredded into smaller pieces, dried at $25 \pm 2{ }^{\circ} \mathrm{C}$, ground into powder, filtered into fine particles and then extracted.

\subsection{Extraction Procedure for Dry Leaf Powder Samples}

$50 \mathrm{~g}$ of dried and powdered Terminalia glaucescens stem was extracted in $150 \mathrm{ml}$ of chloroform, ethanol and ethyl acetate for a duration of $48 \mathrm{hrs}$. The solvents were separated using sterile muslin cloth and sieved through sterile Whatmann filter paper (No. 01). The resultant extract in solvents was evaporated to dryness in a rotary evaporator and used as crude extract. The dry crude extracts were used for antimicrobial and phytochemical studies.

\subsection{Preliminary Phytochemicals Screening}

The phytochemical screening of the extracts was investigated according to the methods of Harborne [45] with little modifications as follows;

\subsubsection{Saponins}

The presence of saponin was detected by froth test. Exactly $500 \mathrm{mg}$ of extract was measured into a $250 \mathrm{ml}$ conical flask with $25 \mathrm{ml}$ of sterile distilled water and heated for 5 minutes. This was then sieved and after which $2.5 \mathrm{ml}$ of the filtrate was added to $10 \mathrm{ml}$ of sterile distilled water in a test tube. The mixture was then vigorously shaken for about 30 
seconds and left for 30 minutes. Honeycomb froth showed the presence of saponins.

\subsubsection{Alkaloids}

Alkaloid test was carried out by measuring $2 \mathrm{ml}$ of chloroform into a test tube to which few drops of Wagners reagent and $1 \mathrm{ml}$ of the crude filtrate solution were added. A reddish brown precipitate formation indicated the presence of alkaloids.

\subsubsection{Tannins}

To investigate the presence of tannins, to a portion of crude filtrate solution in distilled water, about 4 drops of $20 \%$ ferric chloride solution were carefully added. The formation of green, blue or blue-black colour indicated the presence of tannins.

\subsubsection{Reducing Sugars}

To $0.5 \mathrm{ml}$ of extracts $1 \mathrm{ml}$ of water and few drops of Fehling's solution were added. The mixture was heated over water-bath and the formation of brick red precipitate confirmed the presence of reducing sugars.

\subsubsection{Terpenoids}

The presence of terpenoids was confirmed by adding $1 \mathrm{ml}$ of crude extract solution to $2 \mathrm{ml}$ chloroform followed by the addition of acetic anhydride $(1 \mathrm{ml})$. One milliliter of concentrated sulphuric acid was carefully introduced to the solution. The formation of red violet colour mixture showed the presence of terpenoids.

\subsubsection{Flavonoids}

Few drops of diluted sodium hydroxide solution was added to $0.5 \mathrm{ml}$ extract. A deep yellow colour mixture which became colourless upon the addition of few drops of diluted $\mathrm{H}_{2} \mathrm{SO}_{4}$ acid proved the presence of flavonoids.

\subsubsection{Steroids}

About $0.5 \mathrm{ml}$ of acetic anhydride and few drops of concentrated $\mathrm{H}_{2} \mathrm{SO}_{4}$ were added to $1 \mathrm{ml}$ of extract filtrate. A blue-green precipitate shows the presence of steroids.

\subsubsection{Anthraquinones}

To $10 \mathrm{ml}$ of chloroform, $1 \mathrm{ml}$ of the crude filtrate solution was added. A yellowish green precipitate observed in the mixture indicated the presence of anthraquinones.

\subsubsection{Phlobatannins}

To $1 \mathrm{ml}$ of extract solution, few drops of $1 \% \mathrm{HCl}$ were added. Reddish brown colouration was observed in the presence of phlobatannins.

\subsection{Antimicrobial Activity Study}

Extracts preparation: Crude extract of the $T$. glaucescens, was prepared as different concentrations in different solvents through serial dilution in appropriate solvents (ethanol, ethyl acetate and chloroform) to give $(500 \mathrm{mg} / \mathrm{ml}, 250$ $\mathrm{mg} / \mathrm{ml}, 100 \mathrm{mg} / \mathrm{ml}, 50 \mathrm{mg} / \mathrm{ml}$ and $25 \mathrm{mg} / \mathrm{ml}$ designated as $\mathrm{C}_{5}, \mathrm{C}_{4}, \mathrm{C}_{3}, \mathrm{C}_{2}$ and $\mathrm{C}_{1}$, respectively) and was used for the antimicrobial screening. The antimicrobial potency test was carried out using the agar disc diffusion method [46]. Whatman No 1 filter paper was used in the preparation of $6.0 \mathrm{~mm}$ diameter discs embedded with extracts at various concentrations and used in the sensitivity test. Negative controls (C) were prepared by using the same solvents employed to dissolve the samples. Inhibition zones were measured and compared with the standard synthetic antibiotics as reference.

Antimicrobial Sensitivity Test: Test organism was swabbed evenly on the surface of the agar plate using sterile swab sticks. Impregnated paper discs containing the plant extract at different concentrations were then arranged radially and pressed slightly and firmly on the inoculated agar surface to ensure even contact. The plates were then incubated at $37{ }^{\circ} \mathrm{C}$ for 24 hours on Nutrient Agar (for bacteria isolates) while the fungal plates (on Potato Dextrose Agar) were incubated at $25 \pm 2{ }^{\circ} \mathrm{C}$ for $48 \mathrm{hrs}$. The level of sensitivity was defined by assessing the diameter (in millimeter) of the 
visible zone of inhibition of microbial growth produced by the dispersion of the infusion. Each method in this experiment was repeated three times.

Test organisms: The bacterial isolates used in this study include Klebsiella spp, E.coli, Pseudomonas auriginosa, Streptococcus pneumoniae and Bacillus aureus. While the fungal isolates were Aspergillus flavus, Aspergillus niger, Trichoderma spp and Candida spp, and the cultures were maintained on nutrient agar and potato dextrose agar, respectively.

Statistical Analysis: The Statistical Package for Social Scientists (SPSS, version 19.0) was used for the analysis of the data obtained. Two way ANOVA test was applied to set the degree of significance of the crude extracts at different concentrations. Also, comparison of the different solvent extractions (i.e. ethanol, ethyl acetate and chloroform) were made statistically; the general antimicrobial effects of the extracts were compared with the standard antibiotics and antifungal disc, respectively.

\section{RESULTS}

The results obtained from the antimicrobial activity of $T$. glaucescens on the test organisms are presented in Tables $\mathbf{2}$ to $\mathbf{5}$. The data were analyzed statistically and the significance level was obtained at $\mathrm{p}<0.05$. Values are shown as mean \pm standard deviation (SD) for each immersion. Values with $(*)$ are significantly higher than the control at $\mathrm{p}<0.05$.

Table 2. Diameter Zones of Inhibition (mm) of the Crude Extract of T. glaucescens Against Tested Bacterial Isolates.

\begin{tabular}{|c|c|c|c|c|c|c|c|}
\hline \multicolumn{8}{|c|}{ Zones of inhibition of different extracts } \\
\hline & & \multicolumn{2}{|c|}{ Ethanol (mm) } & \multicolumn{2}{|c|}{ Ethyl Acetate(mm) } & \multicolumn{2}{|c|}{ Chloroform(mm) } \\
\hline \multirow[t]{6}{*}{ P. aeruginosa } & $\mathrm{C}$ & 8.50 & \pm 0.707 & 7.50 & \pm 0.707 & 7.00 & \pm 0.000 \\
\hline & $\mathrm{C}_{1}$ & 9.50 & \pm 0.707 & 8.50 & \pm 0.707 & 7.50 & \pm 0.707 \\
\hline & $\mathrm{C}_{2}$ & 11.50 & $\pm 0.707^{*}$ & 9.00 & \pm 1.414 & 8.50 & \pm 0.707 \\
\hline & $\mathrm{C}_{3}$ & 11.50 & $\pm 0.707 *$ & 11.50 & $\pm 0.707^{*}$ & 8.50 & \pm 0.707 \\
\hline & $\mathrm{C}_{4}$ & 13.50 & $\pm 0.707^{*}$ & 12.00 & $\pm 1.414^{*}$ & 9.50 & \pm 0.707 \\
\hline & $\mathrm{C}_{5}$ & 14.50 & $\pm 0.707 *$ & 13.50 & $\pm 0.707^{*}$ & 10.50 & $\pm 0.707^{*}$ \\
\hline \multirow[t]{6}{*}{ Klebsiella $\mathrm{sp}$} & $\mathrm{C}$ & 9.00 & \pm 1.414 & 7.50 & \pm 0.707 & 7.00 & \pm 0.000 \\
\hline & $\mathrm{C}_{1}$ & 8.50 & \pm 2.121 & 7.50 & \pm 0.707 & 7.50 & \pm 0.707 \\
\hline & $\mathrm{C}_{2}$ & 9.50 & \pm 0.707 & 8.50 & \pm 0.707 & 8.00 & \pm 0.000 \\
\hline & $\mathrm{C}_{3}$ & 11.50 & \pm 0.707 & 10.00 & \pm 0.000 & 8.50 & \pm 0.707 \\
\hline & $\mathrm{C}_{4}$ & 12.00 & $\pm 1.414^{*}$ & 10.50 & $\pm 0.707^{*}$ & 8.50 & \pm 0.707 \\
\hline & $\mathrm{C}_{5}$ & 13.50 & $\pm 0.707^{*}$ & 11.50 & $\pm 0.707^{*}$ & 10.00 & $\pm 0.000^{*}$ \\
\hline \multirow[t]{6}{*}{ E. coli } & $\mathrm{C}$ & 8.50 & \pm 0.707 & 7.00 & \pm 0.000 & 7.50 & \pm 0.707 \\
\hline & $\mathrm{C}_{1}$ & 10.50 & \pm 0.707 & 8.50 & \pm 0.707 & 8.00 & \pm 01.414 \\
\hline & $\mathrm{C}_{2}$ & 14.00 & $\pm 1.414^{*}$ & 9.50 & \pm 0.707 & 8.50 & \pm 0.707 \\
\hline & $\mathrm{C}_{3}$ & 15.00 & $\pm 1.414^{*}$ & 11.00 & $\pm 0.000^{*}$ & 9.50 & \pm 0.707 \\
\hline & $\mathrm{C}_{4}$ & 18.00 & $\pm 1.414^{*}$ & 12.50 & $\pm 0.707^{*}$ & 11.50 & \pm 0.707 \\
\hline & $\mathrm{C}_{5}$ & 20.00 & $\pm 1.414^{*}$ & 13.00 & $\pm 1.414^{*}$ & 13.50 & $\pm 02.121^{*}$ \\
\hline \multirow[t]{6}{*}{ S. pneumonia } & $\mathrm{C}$ & 8.50 & \pm 0.707 & 7.00 & \pm 0.000 & 7.50 & \pm 0.707 \\
\hline & $\mathrm{C}_{1}$ & 12.00 & \pm 1.414 & 8.50 & \pm 0.707 & 8.00 & \pm 0.000 \\
\hline & $\mathrm{C}_{2}$ & 14.00 & $\pm 1.414^{*}$ & 9.50 & \pm 0.707 & 7.50 & \pm 0.707 \\
\hline & $\mathrm{C}_{3}$ & 17.00 & $\pm 1.414^{*}$ & 12.00 & $\pm 1.414^{*}$ & 8.50 & \pm 0.707 \\
\hline & $\mathrm{C}_{4}$ & 19.00 & $\pm 0.000^{*}$ & 14.50 & $\pm 0.707^{*}$ & 10.50 & $\pm 0.707^{*}$ \\
\hline & $\mathrm{C}_{5}$ & 20.50 & $\pm 0.707 *$ & 17.50 & $\pm 0.707^{*}$ & 13.50 & $\pm 0.707^{*}$ \\
\hline \multirow[t]{6}{*}{ B. cereus } & $\mathrm{C}$ & 8.50 & \pm 0.707 & 7.00 & \pm 0.000 & 8.00 & \pm 0.000 \\
\hline & $\mathrm{C}_{1}$ & 12.00 & \pm 1.414 & 9.00 & \pm 1.414 & 10.50 & \pm 0.707 \\
\hline & $\mathrm{C}_{2}$ & 15.00 & $\pm 1.414^{*}$ & 12.50 & $\pm 0.707^{*}$ & 13.00 & $\pm 1.414^{*}$ \\
\hline & $\mathrm{C}_{3}$ & 16.00 & $\pm 1.414^{*}$ & 13.50 & $\pm 0.707^{*}$ & 14.00 & $\pm 1.414^{*}$ \\
\hline & $\mathrm{C}_{4}$ & 18.50 & $\pm 0.707 *$ & 13.50 & $\pm 2.121^{*}$ & 16.00 & $\pm 1.414^{*}$ \\
\hline & $\mathrm{C}_{5}$ & 19.00 & $\pm 1.414^{*}$ & 16.00 & $\pm 1.414^{*}$ & 17.50 & $\pm 0.707 *$ \\
\hline
\end{tabular}

Values are expressed as mean $\pm S D$ for $n=2$ for each concentration. Values with (*) are significantly higher than the control at $p<0.05$. C-Control, $\mathrm{C}_{1}-25 \mathrm{ml}, \mathrm{C}_{2}-50 \mathrm{ml}, \mathrm{C}_{3}-100 \mathrm{ml}, \mathrm{C}_{4}-250 \mathrm{ml}, \mathrm{C}_{5}-500 \mathrm{ml}$ 
Table 3. Diameter Zones of Inhibition (mm) of the Crude Extract of T. glaucescens Against Tested Fungal Isolates.

\begin{tabular}{|c|c|c|c|c|c|c|c|}
\hline \multicolumn{8}{|c|}{ Zones of inhibition of different extracts } \\
\hline & & & (mm) & & e(mm) & & $(\mathrm{mm})$ \\
\hline \multirow[t]{6}{*}{ A. flavus } & $\mathrm{C}$ & 8.50 & \pm 0.707 & 7.50 & \pm 0.707 & 7.00 & \pm 0.000 \\
\hline & $\mathrm{C}_{1}$ & 12.00 & \pm 2.828 & 9.50 & \pm 0.707 & 9.50 & \pm 2.121 \\
\hline & $\mathrm{C}_{2}$ & 13.50 & \pm 2.121 & 12.00 & $\pm 1.414^{*}$ & 10.50 & \pm 0.707 \\
\hline & $\mathrm{C}_{3}$ & 17.00 & $\pm 1.414^{*}$ & 13.00 & $\pm 1.414^{*}$ & 14.50 & $\pm 2.121 *$ \\
\hline & $\mathrm{C}_{4}$ & 17.50 & $\pm 0.707 *$ & 14.50 & $\pm 0.707^{*}$ & 15.50 & $\pm 2.121 *$ \\
\hline & $\mathrm{C}_{5}$ & 19.00 & $\pm 1.414^{*}$ & 15.50 & $\pm 0.707^{*}$ & 17.00 & $\pm 1.414^{*}$ \\
\hline \multirow[t]{6}{*}{ A. niger } & $\mathrm{C}$ & 7.50 & \pm 0.707 & 7.00 & \pm 0.000 & 7.00 & \pm 0.000 \\
\hline & $\mathrm{C}_{1}$ & 11.00 & \pm 1.414 & 8.50 & \pm 0.707 & 10.00 & \pm 1.414 \\
\hline & $\mathrm{C}_{2}$ & 14.00 & $\pm 1.414^{*}$ & 11.00 & $\pm 1.414^{*}$ & 13.00 & $\pm 1.414^{*}$ \\
\hline & $\mathrm{C}_{3}$ & 17.50 & $\pm 0.707^{*}$ & 13.50 & $\pm 0.707^{*}$ & 15.50 & $\pm 0.707^{*}$ \\
\hline & $\mathrm{C}_{4}$ & 18.50 & $\pm 0.707 *$ & 13.00 & $\pm 1.414^{*}$ & 16.50 & $\pm 0.707 *$ \\
\hline & $\mathrm{C}_{5}$ & 19.00 & $\pm 0.000^{*}$ & 15.50 & $\pm 0.707^{*}$ & 17.50 & $\pm 0.707 *$ \\
\hline \multirow[t]{6}{*}{ Trichoderma $\mathrm{sp}$} & $\mathrm{C}$ & 8.50 & \pm 0.707 & 7.00 & \pm 0.000 & 7.50 & \pm 0.707 \\
\hline & $\mathrm{C}_{1}$ & 9.00 & \pm 1.414 & 8.50 & \pm 0.707 & 9.50 & \pm 0.707 \\
\hline & $\mathrm{C}_{2}$ & 10.00 & \pm 1.414 & 8.00 & \pm 1.414 & 9.00 & \pm 1.414 \\
\hline & $\mathrm{C}_{3}$ & 11.00 & \pm 1.414 & 8.50 & \pm 0.707 & 10.00 & \pm 1.414 \\
\hline & $\mathrm{C}_{4}$ & 14.00 & $\pm 1.414^{*}$ & 11.00 & $\pm 1.414^{*}$ & 12.50 & $\pm 0.707 *$ \\
\hline & $\mathrm{C}_{5}$ & 19.00 & $\pm 1.414^{*}$ & 12.50 & $\pm 0.707^{*}$ & 16.00 & $\pm 1.414^{*}$ \\
\hline \multirow[t]{6}{*}{ Candida $\mathrm{sp}$} & $\mathrm{C}$ & 8.00 & \pm 1.414 & $\mathrm{C}$ & \pm 0.000 & 7.50 & \pm 0.707 \\
\hline & $\mathrm{C}_{1}$ & 11.00 & \pm 1.414 & 9.00 & \pm 1.414 & 10.00 & \pm 1.414 \\
\hline & $\mathrm{C}_{2}$ & 13.00 & \pm 1.414 & 9.50 & \pm 0.707 & 11.00 & \pm 1.414 \\
\hline & $\mathrm{C}_{3}$ & 12.00 & \pm 1.414 & 10.00 & \pm 1.414 & 11.00 & \pm 1.414 \\
\hline & $\mathrm{C}_{4}$ & 13.50 & $\pm 0.707^{*}$ & 12.00 & $\pm 0.000^{*}$ & 11.00 & \pm 0.000 \\
\hline & $\mathrm{C}_{5}$ & 15.00 & $\pm 1.414^{*}$ & 12.00 & $\pm 1.414^{*}$ & 13.00 & $\pm 1.414^{*}$ \\
\hline
\end{tabular}

Values are expressed as mean $\pm S D$ for $n=2$ for each concentration. Values with $(*)$ are significantly higher than the control at $p<0.05$. C-Control, $\mathrm{C}_{1}-25 \mathrm{ml}, \mathrm{C}_{2}-50 \mathrm{ml}, \mathrm{C}_{3}-100 \mathrm{ml}, \mathrm{C}_{4}-250 \mathrm{ml}, \mathrm{C}_{5}-500 \mathrm{ml}$

Table 4. Comparative activity of ethanolic extract against Bacteria and fungi isolates.

\begin{tabular}{|c|c|}
\hline Bacteria & Highest zone of inhibition (mm) \\
\hline Ethanol & 20.5 \\
\hline Ethyl acetate & 17.5 \\
\hline Chloroform & 17.5 \\
\hline Fungi & 19.0 \\
\hline Ethanol & 15.5 \\
\hline Ethyl acetate & 17.5 \\
\hline Chloroform & \\
\hline
\end{tabular}

Table 5. Diameter Zones of Inhibition (mm) of the ethanolic extract of T. glaucescens and the standard.

\begin{tabular}{|l|c|c|c|}
\hline \multirow{3}{*}{\begin{tabular}{|} 
P. aeruginosa \\
\cline { 2 - 4 }
\end{tabular}} & STR & 11.50 & Ethanol \\
\cline { 2 - 4 } & $\mathrm{C}_{1}$ & 9.50 & \pm 0.707 \\
\cline { 2 - 4 } & $\mathrm{C}_{2}$ & 11.50 & \pm 0.707 \\
\cline { 2 - 4 } & $\mathrm{C}_{3}$ & 11.50 & \pm 0.707 \\
\cline { 2 - 4 } & $\mathrm{C}_{4}$ & 13.50 & \pm 0.707 \\
\cline { 2 - 4 } & $\mathrm{C}_{5}$ & 14.50 & $\pm 0.707 *$ \\
\hline
\end{tabular}




\begin{tabular}{|c|c|c|c|}
\hline & & & \\
\hline \multirow[t]{6}{*}{ Klebsiella sp } & STR & 10.50 & \pm 0.707 \\
\hline & $\mathrm{C}_{1}$ & 8.50 & \pm 2.121 \\
\hline & $\mathrm{C}_{2}$ & 9.50 & \pm 0.707 \\
\hline & $\mathrm{C}_{3}$ & 11.50 & \pm 0.707 \\
\hline & $\mathrm{C}_{4}$ & 12.00 & \pm 1.414 \\
\hline & $\mathrm{C}_{5}$ & 13.50 & \pm 0.707 \\
\hline \multirow[t]{6}{*}{ E.coli } & STR & 10.00 & \pm 0.000 \\
\hline & $\mathrm{C}_{1}$ & 10.50 & \pm 0.707 \\
\hline & $\mathrm{C}_{2}$ & 14.00 & \pm 1.414 \\
\hline & $\mathrm{C}_{3}$ & 15.00 & $\pm 1.414^{*}$ \\
\hline & $\mathrm{C}_{4}$ & 18.00 & $\pm 1.414^{*}$ \\
\hline & $\mathrm{C}_{5}$ & 20.00 & $\pm 1.414 *$ \\
\hline \multirow[t]{6}{*}{ S. pneumonia } & GEN & 13.50 & \pm 0.707 \\
\hline & $\mathrm{C}_{1}$ & 12.00 & \pm 1.414 \\
\hline & $\mathrm{C}_{2}$ & 14.00 & \pm 1.414 \\
\hline & $\mathrm{C}_{3}$ & 17.00 & \pm 1.414 \\
\hline & $\mathrm{C}_{4}$ & 19.00 & \pm 0.000 \\
\hline & $\mathrm{C}_{5}$ & 20.50 & $\pm 0.707^{*}$ \\
\hline \multirow[t]{6}{*}{ B. cereus } & GEN & 13.00 & \pm 0.000 \\
\hline & $\mathrm{C}_{1}$ & 12.00 & \pm 1.414 \\
\hline & $\mathrm{C}_{2}$ & 15.00 & \pm 1.414 \\
\hline & $\mathrm{C}_{3}$ & 16.00 & \pm 1.414 \\
\hline & $\mathrm{C}_{4}$ & 18.50 & $\pm 0.707^{*}$ \\
\hline & $\mathrm{C}_{5}$ & 19.00 & $\pm 1.414^{*}$ \\
\hline \multirow[t]{6}{*}{ A. flavus } & NIS & 15.00 & \pm 0.000 \\
\hline & $\mathrm{C}_{1}$ & 12.00 & \pm 2.828 \\
\hline & $\mathrm{C}_{2}$ & 13.50 & \pm 2.121 \\
\hline & $\mathrm{C}_{3}$ & 17.00 & \pm 1.414 \\
\hline & $\mathrm{C}_{4}$ & 17.50 & \pm 0.707 \\
\hline & $\mathrm{C}_{5}$ & 19.00 & \pm 1.414 \\
\hline \multirow[t]{6}{*}{ A. niger } & NIS & 16.50 & \pm 0.707 \\
\hline & $\mathrm{C}_{1}$ & 11.00 & \pm 1.414 \\
\hline & $\mathrm{C}_{2}$ & 14.00 & \pm 1.414 \\
\hline & $\mathrm{C}_{3}$ & 17.50 & \pm 0.707 \\
\hline & $\mathrm{C}_{4}$ & 18.50 & \pm 0.707 \\
\hline & $\mathrm{C}_{5}$ & 19.00 & \pm 0.000 \\
\hline \multirow[t]{6}{*}{ Trichoderma $\mathrm{sp}$} & NIS & 14.00 & \pm 0.000 \\
\hline & $\mathrm{C}_{1}$ & 9.00 & \pm 1.414 \\
\hline & $\mathrm{C}_{2}$ & 10.00 & \pm 1.414 \\
\hline & $\mathrm{C}_{3}$ & 11.00 & \pm 1.414 \\
\hline & $\mathrm{C}_{4}$ & 14.00 & \pm 1.414 \\
\hline & $\mathrm{C}_{5}$ & 19.00 & \pm 1.414 \\
\hline \multirow[t]{6}{*}{ Candida $\mathrm{sp}$} & NIS & 14.00 & \pm 0.000 \\
\hline & $\mathrm{C}_{1}$ & 11.00 & \pm 1.414 \\
\hline & $\mathrm{C}_{2}$ & 13.00 & \pm 1.414 \\
\hline & $\mathrm{C}_{3}$ & 12.00 & \pm 1.414 \\
\hline & $\mathrm{C}_{4}$ & 13.50 & \pm 0.707 \\
\hline & $\mathrm{C}_{5}$ & 15.00 & \pm 1.414 \\
\hline
\end{tabular}




\subsection{Antimicrobial Effect of Crude Extracts of Terminalia glaucescens}

The antimicrobial activities of ethanol, chloroform and ethyl acetate extract of $T$. glaucescens with respect to their zones of inhibition $(\mathrm{mm})$ on the test organisms are shown in Tables $\mathbf{2}$ to 4 . All the extracts showed potential antimicrobial activities against the test organisms. The antimicrobial activity of the extracts increased with increase in extract concentrations.

Ethanolic extract: Ethanolic extract $\left(\mathrm{C}_{1}-\mathrm{C}_{5}\right)$ effectively inhibited majority of the test organisms and was comparatively better in antimicrobial performance than the control. The zone of inhibition against test organisms ranged from $8.5 \mathrm{~mm}$ at $\mathrm{C}_{1}-$ to $20.5 \mathrm{~mm}$ at $\mathrm{C}_{5}$. The extract shows inhibition against test fungi with zones of inhibition ranging from $9.0 \mathrm{~mm}$ at $\mathrm{C}_{1}-19.0 \mathrm{~mm}$ at $\mathrm{C}_{5}$ while zones of inhibition against bacteria isolates tested ranged between $8.50 \mathrm{~mm}$ at $\mathrm{C}_{1}-20.5 \mathrm{~mm}$ at $\mathrm{C}_{5}$. Ethanolic extract at concentration $\mathrm{C}_{5}(500 \mathrm{mg} / \mathrm{ml})$ showed consistently higher zones of inhibition against $S$. pneumonia $(20.5 \mathrm{~mm})$, E.coli $(20.0 \mathrm{~mm})$, B. cereus, A. niger, Trichoderma sp. and A. flavus (19.0 mm) respectively, while the lowest zone of inhibition at this concentration was recorded against Klebsiella sp with a diameter of $13.5 \mathrm{~mm}$ which is, however, higher than the performance of the control with a record range of $8.50 \mathrm{~mm}-9.00 \mathrm{~mm}$.

Ethyl acetate extract: Ethyl acetate extract like ethanolic extract effectively inhibited the growth of all tested bacteria and fungi and performed better than the control except for activity against Klebsiella sp where the performances were comparatively the same with the control and recorded as $7.50 \mathrm{~mm}$. The range of inhibition of the extract was from $7.5 \mathrm{~mm}$ at $\mathrm{C}_{1}-17.5 \mathrm{~mm}$ at $\mathrm{C}_{5}$. Ethyl acetate extract recorded zone of inhibition against test fungal isolates in the range of $8.0 \mathrm{~mm}$ at $\mathrm{C}_{2}-15.5 \mathrm{~mm}$ at $\mathrm{C}_{5}$ while zones of inhibition against bacteria isolates tested ranged from $7.50 \mathrm{~mm}$ at $\mathrm{C}_{1}-17.5 \mathrm{~mm}$ at $\mathrm{C}_{5}$. The highest zone of inhibition recorded for ethyl acetate was observed at 500 $\mathrm{mg} / \mathrm{ml}$ against $S$. pneumonia with a diameter of $17.5 \mathrm{~mm}$ while the lowest zone of inhibition at the same concentration was recorded against Klebsiella $\mathrm{sp}$ with a diameter of $11.5 \mathrm{~mm}$.

Chloroform extract: In a similar manner as Ethanol and Ethyl acetate extracts, the chloroform extract exhibited antibacterial and antifungal activities against the test isolates with zones of inhibition against bacteria isolates ranging from $7.50 \mathrm{~mm}$ at $\mathrm{C}_{1}-17.5 \mathrm{~mm}$ at $\mathrm{C}_{5}$. It was also comparatively better in antimicrobial performance than the control. The extract exhibited inhibition against tested fungal isolates in the range of $9.0 \mathrm{~mm}$ at $\mathrm{C}_{2}-17.5 \mathrm{~mm}$ at $\mathrm{C}_{5}$. The highest zone of inhibition was also recorded at $500 \mathrm{mg} / \mathrm{ml}$ against $B$. cereus and A. niger with a diameter of $17.5 \mathrm{~mm}$ in each case, while the lowest zone of inhibition for the same concentration was recorded against Klebsiella sp with a diameter of $10.0 \mathrm{~mm}$.

Comparative activities of extracts: Ethanolic extract performs better than ethyl acetate and chloroform extracts as it recorded the highest zone of inhibition of $20.5 \mathrm{~mm}$ against Streptococcus pneumoniae while ethyl acetate and chloroform recorded $17.50 \mathrm{~mm}$ each against Streptococcus pneumoniae and Bacillus cereus, respectively (Table 4). The extracts of Terminalia glaucescens seem to exhibit a good antibacterial activity against Streptococcus pneumoniae and Bacillus sp and lesser activity against Klebsiella sp. The extract exhibited higher antifungal activity against Trichoderma sp. and Aspergillus niger (Table 4).

Crude extract of ethanol at the highest concentration $\mathrm{C}_{5}$ tested was a more potent antimicrobial agent when further compared with standard (Gentamicin, Streptomycin and Nystatin). Ethanolic extract recorded higher zones of inhibition against Pseudomonas aeruginosa, Klebsiella sp and E. coli as $14.5 \mathrm{~mm}, 13.5 \mathrm{~mm}$ and $20.0 \mathrm{~mm}$ at $\mathrm{C}_{5}$ while Streptomycin recorded $11.5 \mathrm{~mm}, 10.5 \mathrm{~mm}$ and $10.0 \mathrm{~mm}$, respectively, against the same set of organisms (Table 5). The extract recorded highest zones of inhibition against Streptococcus pnuemoniae and Bacillus cereus as $20.5 \mathrm{~mm}$ and 19.0 $\mathrm{mm}$ at $\mathrm{C}_{5}$ while the record of Gentamycin against the organisms were 13.5 and $13.0 \mathrm{~mm}$, respectively. The ethanolic extract equally exerted zones of inhibition that were comparatively higher than that of nystatin against the tested fungi, but were not statistically different from the values obtained for nystatin $(\mathrm{P}<0.05)$. Higher activities were recorded against Aspergillus flavus, Aspergillus niger and Trichoderma sp; $19.0 \mathrm{~mm}$ at concentration $\mathrm{C}_{5}$, while the least was recorded as $15.0 \mathrm{~mm}$ against Candida $\mathrm{sp}$ at the same concentration. The antimicrobial activity of ethanol was therefore notable against all tested organisms and commercial antibiotics at $\mathrm{C}_{5}(\mathrm{P}<0.05)$. The results are presented in Table 5 . Plates (1 and 2) illustrates reported characteristic antibacterial (against E.coli) and antifungal (against $A$. flavus) activities of ethanolic extracts. 


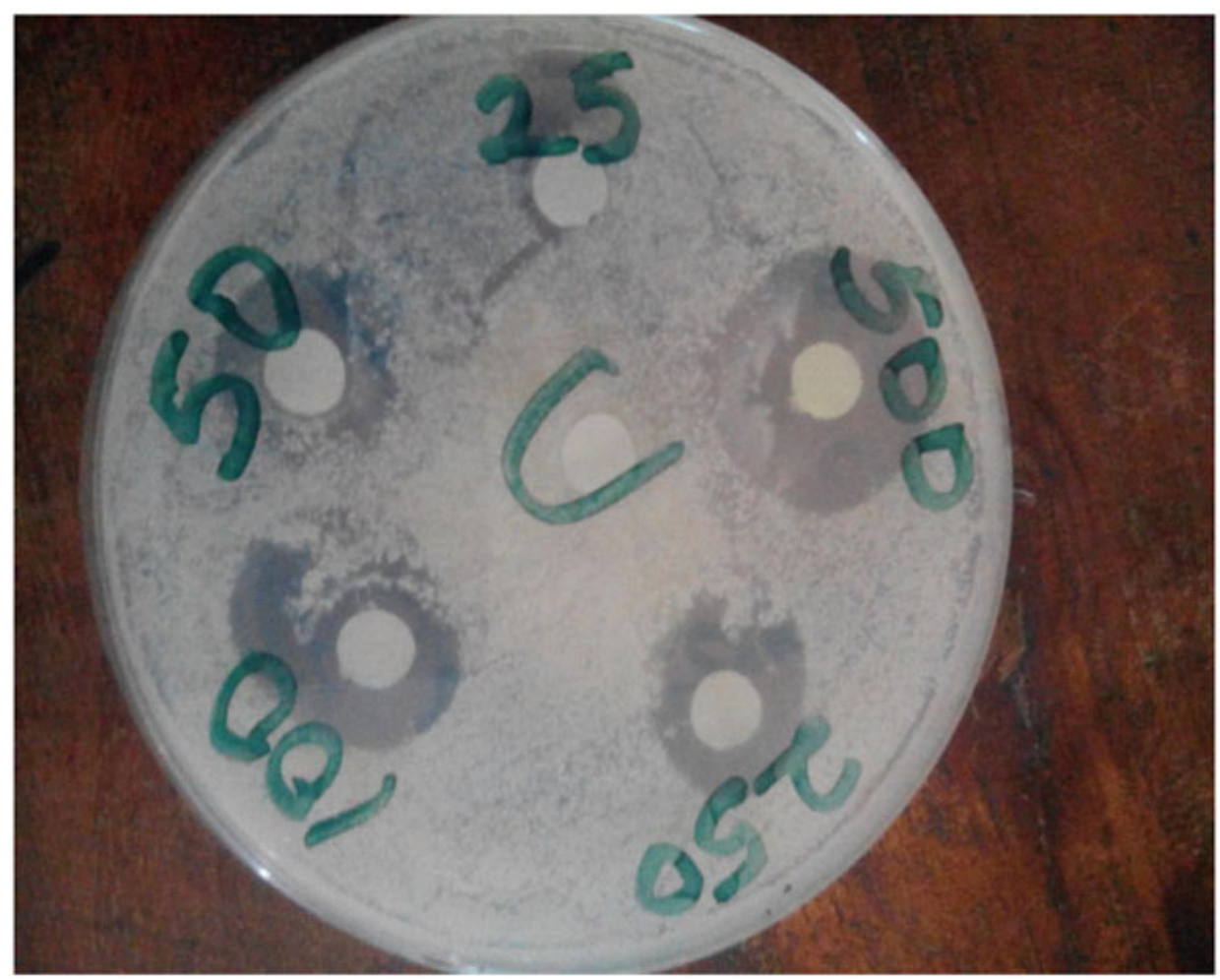

Plate (1). The Zones of Inhibition of Ethanol Crude Extract of T. glaucescens on E. coli $\mathrm{C}-$ Control consisting of solvent without crude extract, 25-500 - Amount of crude extract dissolve in $1 \mathrm{ml}$ of solvent.

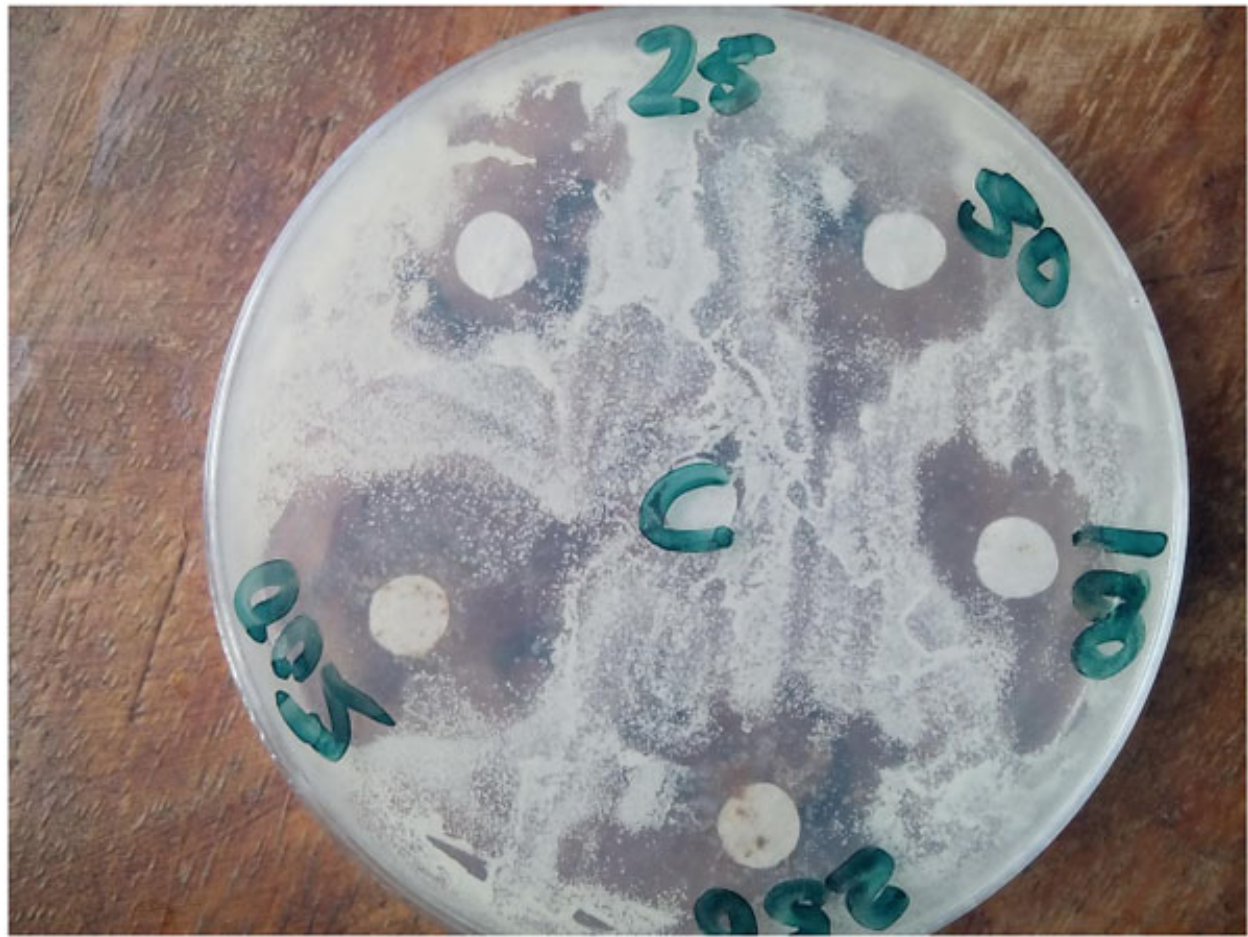

Plate (2). The Zones of Inhibition of Ethanol Crude Extract of T. glaucescens on A. flavus $\mathrm{C}$ - Control consisting of solvent without crude extract 25-500 - Amount of crude extract dissolve in $1 \mathrm{ml}$ of solvent. 


\subsection{Phytochemical Screening of Terminalia glaucescens}

The results obtained from the qualitative phytochemical screening of Terminalia glaucescens are presented in Table 6. In ethanol, saponins, tannins, alkaloids, flavonoids, terpenoids, steroids and anthraquinones were present while reducing sugars and phlobatannins were absent. In ethyl acetate and chloroform, saponins, tannins, alkaloids, terpenoids, steroids and anthraquinones were present while Reducing sugars, Phlobatannins and Flavonoids were absent.

Table 6. Phytochemical Analysis Results of T. glaucescens.

\begin{tabular}{|c|c|c|c|}
\hline & Ethanol & Ethyl Acetate & Chloroform \\
\hline Saponins & + & + & + \\
\hline Tannins & + & + & + \\
\hline Reducing Sugars & - & + & - \\
\hline Alkaloids & + & - & + \\
\hline Flavonoids & + & + & + \\
\hline Terpenoids & + & - & - \\
\hline Phlobatannins & + & + & + \\
\hline Steroids & + & + & + \\
\hline
\end{tabular}

$+=$ Present,

$-=$ Absent

\section{DISCUSSION}

\subsection{Comparative Activities of Plant Extracts and Commercial Antibiotics}

Tables $\mathbf{2}$ to $\mathbf{5}$ present the summary of the antibacterial and antifungal activities of the various extracts of Terminalia glaucescens and that of selected commercial antibiotics against different fungal and bacterial strains tested. Antimicrobial activities were found in all the plant extracts and with remarkable zones of inhibitions. The antibacterial and antifungal activities of active extracts were observed in the increasing order of Ethanol $>$ Chloroform $\geq$ ethyl acetate with respect to the maximum zone of inhibition. Ethanolic extract compared favourably against commercial streptomycin, gentamycin and nystatin which were used as standards with significant statistical differences. The zones of inhibition reported in this study against bacterial isolates tested ranged from 7.5 to $20.5 \mathrm{~mm}$ while that recorded against fungal isolates ranged from 8.0 to $19.0 \mathrm{~mm}$. The extent of antimicrobial activity of extract based on the zone of inhibition has been described as low (12-18 mm), moderate (19-22 mm) and strong (23-38 $\mathrm{mm})$ [47], we may therefore infer that ethanolic extract of $T$. glaucescens which exhibited inhibitions in a range of 18.0-20.0 mm against most of the microbial strain tested has considerable antimicrobial activity. Previous screening by earlier researchers had demonstrated the antimicrobial efficacy of variuos plant extracts including Holarrhenea antidyssentrica [48]; Tapinthus senssilifolius [49]; Rauelfia tetraphylla and Physalis minima [50]; Achillea santolina, Salvia dominica and Salvia officinalis [51]; Psidium guajava and Mangifera indica [52] and Salicornia brachiata [53] against different bacteria and fungal isolates. Viji et al. [17], have demonstrated that ethanolic and chloroform extracts can potentially be used against E. coli, Pseudomonas aeruginosa, Bacillus sp and Klebsiella sp. which were used in this study.

\subsection{Phytochemicals}

Plants are known to contain a number of phytochemicals such as flavonoids, saponins, tannins and other phenolic compounds that have antimicrobial activities [54 - 56]. The results of phytochemical screening in $T$. glaucescens reveal the presence of saponins, tannins, alkaloids, terpenoids, steroids and anthraquinones in all extracts investigated. Reducing sugars and phlobatannins were absent. Flavonoids was however present in ethanolic extract but not in ethyl acetate and chloroform extracts. The presence of antifungal and antimicrobial substances in higher plants is well established as they have provided a source of inspiration for novel drug compounds [17]. This suggests that the antimicrobial activities of the plant under investigation may be as a result of the phytochemicals present.

\subsection{Antimicrobial Responses and Mechanisms}

It was noted that all the extracts exhibited antibiosis against gram positive and gram negative bacteria as well as the tested fungal isolates (broad spectrum activities). Noteworthy, is the activity of the ethanolic extract at $500 \mathrm{mg} / \mathrm{ml}$ against Streptococcus pneumoniae $(20.5 \mathrm{~mm})$, E.coli $(20 \mathrm{~mm})$ and B. cereus $(19.0 \mathrm{~mm})$. The values of zones of 
inhibitions show that ethanolic extract performed better than ethyl acetate and chloroform extracts. The susceptibility of the tested microbes to the extracts varies across the different solvents of extraction. This suggests that ethanolic extracts of $T$. glaucescens was more effective than ethyl acetate and chloroform extract. The variation in responses of the various microbial strains to individual extracts may be attributed to the nature of the microbial cells and their genetic diversity [57]. The chemistry of the extracting solvent and subsequent bio-active components extracted by various solvents may also explain the difference in antimicrobial potency of the extract in different solvents [16], which may affect overall activity [57]. Resistance could be due to the permeability barrier provided by the cell wall or to the membrane accumulation mechanism [58].

Variation in phytochemical components of the various extracts may result from variance in the chemistry of the extracting solvent which selectively affect extraction of various bio-active metabolites. The mechanisms of antimicrobial actions of these compounds may be via cell membranes perturbations [59] and may involve diverse molecular modes, such as binding and increasing the permeability of cell wall and membrane component [60]. These induce membrane destabilization, leakage of cytoplasmic contents, loss of membrane potential, change of membrane permeability, lipid distribution, the entry of the peptide and blocking of anionic cell components or the triggering of autolytic enzymes and the final death of the microbial cell [61]. This finding is similar to that of Dahot [62] who reported that plant extract from $M$. oleifera had antimicrobial activity against E. coli, S. aureus and B. subtilis. Dahot [62], however, reported resistance from Aspergillus niger and Aspergillus flavus from which notable susceptibility was recorded in this study. The curative advantage of such a plant used in this finding is that consumers including animals tend to consume the plant material in large quantities and in high concentrations. This suggests the ability of the plant to meet the required physiological levels to inhibit the pathogenic growth in situ and point to the potential of $T$. glaucescens as biocides to be explored in various fields. The differences in ethanolic extract activity from that of ethyl acetate and chloroform extracts as well as the similarities in the activities of ethyl acetate and chloroform extracts follow the pattern observed in the similarities and differences in phytochemical compositions of the extracts (Table 6). This may suggest the positive contributions of these phytochemicals in the antimicrobial activities of the extracts.

There exist reports to show that the mechanism of water purification by plant material is associated with their flocculating, coagulative and disinfecting properties [63]. Polysaccharides as well as protein associated phyto-chemicals have been implicated in the purification process. The phytochemicals may form flocs which settles slowly while sweeping out suspended impurities in water. Phytochemicals with their net charge; either positive, negative or neutral are thought to combine with active sides of colloids and impurities; such interaction produces a bridging effect, binding impurities and phytochemicals together into a large particle which settles under the action of gravity. The disinfecting properties of lemon and moringa extracts in water have been partly associated with ability to alter the $\mathrm{pH}$ of water, making it unsuitable for some living contaminants $[5,64,65]$ while the effectiveness in coagulation and colour reduction is a function of particles size and concentration [66].

While some of the current chemical compounds like alum and chlorine used in disinfecting water has been tagged a precursor for cancer, as it forms tetrahalomethane compounds and lead to hormone mimics as well as generating dementia in young and elderly, reports exist to show that plant based technology are at different stages of development for water purification. The technology will be very simple, non-toxic and with no major machinery nor specialized labour needed $[5,67]$.

In this study, T. glaucescens extracts had a dose dependent bactericidal properties against all bacterial strains which are mostly known to be multi-resistant $[6,8]$. According to several authors, these bacteria are generally less sensitive to the activity of plant extracts $[68,69]$. The ability of the extracts to antagonise and exhibit broad spectrum antibiosis is therefore noteworthy. The plant ethanolic extracts with optimal antimicrobial performance can therefore be recommended for further research in development of potent antimicrobial agents against multidrug and emerging resistant microbes.

\section{CONCLUSION}

The present study which was aimed at establishing the antimicrobial efficacy of different crude extracts of $T$. glaucescens showed that the crude extracts from the plant possessed potent activity against the employed bacteria and fungi. Similarly, phytochemical screening showed that the antimicrobial activities of the crude extracts of the plant may depend on the presence of phytochemicals such as saponins, tannins, alkaloids, flavonoids, terpenoids, steroids and anthraquinones. This plant crude extracts could serve as potential sources of new antimicrobials and for green and ecofriendly water treatment technology development. 


\section{RECOMMENDATIONS}

Further research is needed towards isolation and identification of active metabolites present in the extracts which could be adopted for different biotechnological uses.

\section{ETHICS APPROVAL AND CONSENT TO PARTICIPATE}

Not applicable.

\section{HUMAN AND ANIMAL RIGHTS}

No Animals/Humans were used for studies of this research.

\section{CONSENT FOR PUBLICATION}

Not applicable.

\section{CONFLICT OF INTEREST}

The authors declare no conflict of interest, financial or otherwise.

\section{ACKNOWLEDGEMENTS}

Declared None.

\section{REFERENCES}

[1] Granum PE, Lund T. Bacillus cereus and its food poisoning toxins. FEMS Microbiol Lett 1997; 157(2): 223-8. [http://dx.doi.org/10.1111/j.1574-6968.1997.tb12776.x] [PMID: 9435100]

[2] Fraser CM. The Merck Veterinary Manual. $6^{\text {th }}$ ed. New Jersey: Merck 1986.

[3] Samson RA, Houbraken J, Summerbell RC, Flannigan B, Miller JD. Common and important species of fungi and actinomycetes in door environment.Micro-organisms on home and indoor work environments. New York: Taylor and Francis 2001; pp. $287-92$.

[4] Klich MA. Aspergillus flavus: The major producer of aflatoxin. Mol Plant Pathol 2007; 8(6): 713-22. [http://dx.doi.org/10.1111/j.1364-3703.2007.00436.x] [PMID: 20507532]

[5] Yongabi KA. Biocoagulants for Water and Waste Water Purification: A Review International Review of Chemical Engineering 2010; 2: 444-58.

[6] Afolayan AJ. Extracts from the shoots of Arcotis arctotoides inhibit the growth of bacteria and fungi. Pharm Biol 2003; $41: 22-5$. [http://dx.doi.org/10.1076/phbi.41.1.22.14692]

[7] Pfaller MA, Diekema DJ. Rare and emerging opportunistic fungal pathogens: Concern for resistance beyond Candida albicans and Aspergillus fumigatus. J Clin Microbiol 2004; 42(10): 4419-31. [http://dx.doi.org/10.1128/JCM.42.10.4419-4431.2004] [PMID: 15472288]

[8] Boussaada O, Ammar S, Saidana D, et al. Chemical composition and antimicrobial activity of volatile components from capitula and aerial parts of Rhaponticum acaule DC growing wild in Tunisia. Microbiol Res 2008; 163(1): 87-95. [http://dx.doi.org/10.1016/j.micres.2007.02.010] [PMID: 17482441]

[9] Chouhan S. Enumeration of standard plate count bacteria in raw water supplies. Journal of Environmental Science. Toxicol Food Technol 2015; 9: 2319-4012.

[10] Nandita D, Uchechukwu S, Tomilola DA. Physicochemical and microbiological assessment of Lagos lagoon water, Lagos Nigeria. J Pharmacy Biol Sci 2015; 10: 2319-7676.

[11] Sisti M, Albano A, Brandi G. Bactericidal effect of chlorine on motile Aeromonas spp. in drinking water supplies and influence of temperature on disinfection efficacy. Lett Appl Microbiol 1998; 26(5): 347-51. [http://dx.doi.org/10.1046/j.1472-765X.1998.00346.x] [PMID: 9674163]

[12] Sidhu J, Gibbs RA, Ho GE, Unkovich I. Selection of Salmonella typhimurium as an indicator for pathogen regrowth potential in composted biosolids. Lett Appl Microbiol 1999; 29(5): 303-7.

[http://dx.doi.org/10.1046/j.1365-2672.1999.00626.x] [PMID: 10664970]

[13] Aliero AA, Afolayan AJ. Antimicrobial activity of Solanum tomentosum. Afr J Biotechnol 2006; 5: 369-72.

[14] Marchese A, Schito GC. Resistance patterns of lower respiratory tract pathogens in Europe. Int J Antimicrob Agents 2000; 16(Suppl. 1): S25-9. [http://dx.doi.org/10.1016/S0924-8579(00)00302-2] [PMID: 11137405]

[15] Poole K. Overcoming antimicrobial resistance by targeting resistance mechanisms. J Pharm Pharmacol 2001; 53(3): 283-94. [http://dx.doi.org/10.1211/0022357011775514] [PMID: 11291743] 
[16] Busani M, Julius MP, Voster M. Antimicrobial activities of Moringa oleifera Lam leaf extracts. Afr J Biotechnol 2012; 11: $2797-802$.

[17] Viji M, Sathiya M, Murugesan S. Phytochemical analysis and antibacterial activity of medicinal plant Cardiospermum helicacabum linn. Pharmacologyonline 2010; 2: 445-56.

[18] Balandrin MF, Klocke JA, Wurtele ES, Bollinger WH. Natural plant chemicals: Sources of industrial and medicinal materials. Science 1985; 228(4704): 1154-60. [http://dx.doi.org/10.1126/science.3890182] [PMID: 3890182]

[19] Erdogrul OT. Antimicrobial activities of some plant extracts used in folklore medicine. Pharm Biol 2002; 40: 269-73. [http://dx.doi.org/10.1076/phbi.40.4.269.8474]

[20] Parek J, Karathia N, Chandra S. Screening of some traditionally used medicinal plants for potential antibacterial activity. Indian J Pharm Sci 2006; 68: 832-4. [http://dx.doi.org/10.4103/0250-474X.31031]

[21] Mahomed IM, Ojewole JA. Anticonvulsant activity of Harpagophytum procumbens DC [Pedaliaceae] secondary root aqueous extract in mice. Brain Res Bull 2006; 69(1): 57-62.

[http://dx.doi.org/10.1016/j.brainresbull.2005.10.010] [PMID: 16464685]

[22] Cseke IJ, Kirakosyan A, Kaufman PB, Warber SL, Duke JA, Brielmann HL. Natural product from plants CRC Press. United States of America: Taylor \& Francis Group, LLC 2006.

[23] Adeleye IA, Onubogu CC, Ayolabi CI, Isawumi AO, Nshiogu ME. Screening of crude extracts of twelve medicinal plants and "Wonder -Cure" concoction used in Nigeria unorthodox medicine for activity against mycobacterium tuberculosis isolated from tuberculosis patients sputum. Afr J Biotechnol 2008; 7: 3182-7.

[24] Koudou J, Roblot G, Wylde R. Tannin constituents of Terminalia glaucescens. Planta Med 1995; 61(5): $490-1$. [http://dx.doi.org/10.1055/s-2006-958153] [PMID: 7480219]

[25] Rahman AU, Choudhary MI. Biodiversity as a source of new pharmacophores: A new theory of memory. Pure Appl Chem 2005 ; 77: 75-81.

[26] Ahmad I, Beg AZ. Antimicrobial and phytochemical studies on 45 Indian medicinal plants against multi-drug resistant human pathogens. J Ethnopharmacol 2001; 74(2): 113-23. [http://dx.doi.org/10.1016/S0378-8741(00)00335-4] [PMID: 11167029]

[27] Kim H, Park SW, Park JM, Moon KH, Lee CK. Screening and isolation of antibiotic resistance inhibitors from herb material Resistant Inhibition of 21 Korean plants. Nat Prod Sci 2005; 1: 50-4.

[28] de Morais Lima GR, de Sales IR, Caldas Filho MR, et al. Bioactivities of the genus Combretum (Combretaceae): A review. Molecules 2012; 17(8): 9142-206.

[http://dx.doi.org/10.3390/molecules17089142] [PMID: 22858840]

[29] Saxena VG, Mishra G, Saxena A, Vishwakarma KK. A comparative study on quantitative estimation of tannins in Terminalia chebula, Terminalia belerica, Terminalia arjuna and Saraca indica using spectrophotometer. Asian J Pharm Clin Res 2013; 6: 148-9.

[30] Stace CA. Combretaceae: Flowering plants. Eudicots 2007; 9: 67-82.

[31] Eloff JN, Katerere DR, McGaw LJ. The biological activity and chemistry of the southern African Combretaceae. J Ethnopharmacol 2008; 119(3): 686-99. [http://dx.doi.org/10.1016/j.jep.2008.07.051] [PMID: 18805474]

[32] Yang MH, Vasquez Y, Ali Z, Khan IA, Khan SI. Constituents from Terminalia species increase PPAR $\alpha$ and PPAR $\gamma$ levels and stimulate glucose uptake without enhancing adipocyte differentiation. J Ethnopharmacol 2013; 149(2): 490-8. [http://dx.doi.org/10.1016/j.jep.2013.07.003] [PMID: 23850833]

[33] Bag A, Bhattacharyya SK, Chattopadhyay RR. The development of Terminalia chebula Retz. (Combretaceae) in clinical research. Asian Pac J Trop Biomed 2013; 3(3): 244-52.

[http://dx.doi.org/10.1016/S2221-1691(13)60059-3] [PMID: 23620847]

[34] Pellati F, Bruni R, Righi D, et al. Metabolite profiling of polyphenols in a Terminalia chebula Retzius ayurvedic decoction and evaluation of its chemopreventive activity. J Ethnopharmacol 2013; 147(2): 277-85. [http://dx.doi.org/10.1016/j.jep.2013.02.025] [PMID: 23506992]

[35] Dixit D, Dixit AK, Lad H, Gupta D, Bhatnagar D. Radioprotective effect of Terminalia Chebula Retzius extract against irradiation-induced oxidative stress. Biomed Aging Pathol 2013; 3: 83-8. [http://dx.doi.org/10.1016/j.biomag.2012.10.008]

[36] Liu M, Katerere DR, Gray AI, Seidel V. Phytochemical and antifungal studies on Terminalia mollis and Terminalia brachystemma. Fitoterapia 2009; 80(6): 369-73.

[http://dx.doi.org/10.1016/j.fitote.2009.05.006] [PMID: 19446614]

[37] Nonita PP, Mylene MU. Antioxidant and cytotoxic activities and phytochemical screening of four Philippine medicinal plants. J Med Plants Res 2010; 4: 407-14.

[38] Tom EN, Demougeot C, Mtopi OB, et al. The aqueous extract of Terminalia superba (Combretaceae) prevents glucose-induced hypertension in rats. J Ethnopharmacol 2011; 133(2): 828-33. [http://dx.doi.org/10.1016/j.jep.2010.11.016] [PMID: 21075190] 
[39] Kathirvel A, Sujatha V. In vitro assessment of antioxidant and antibacterial properties of Terminalia chebula Retz. leaves. Asian Pac J Trop Biomed 2012; 2: S788-95. [http://dx.doi.org/10.1016/S2221-1691(12)60314-1]

[40] Fyhrquist P, Laakso I, Garcia-Marco S, Julkunen-Tiitto R, Hiltunen R. Antimycobacterial activity of ellagitannin and ellagic acid derivate rich crude extracts and fractions of five selected species of Terminalia used for treatment of infectious diseases in African traditional medicine. $\mathrm{S}$ Afr J Bot 2014; 90: 1-16. [http://dx.doi.org/10.1016/j.sajb.2013.08.018]

[41] Tom EN, Girard-Thernier C, Martin H, et al. Treatment with an extract of Terminalia superba Engler \& Diels decreases blood pressure and improves endothelial function in spontaneously hypertensive rats. J Ethnopharmacol 2014; 151(1): 372-9. [http://dx.doi.org/10.1016/j.jep.2013.10.057] [PMID: 24212074]

[42] Fahmy NM, Al-Sayed E, Abdel-Daim MM, Karonen M, Singab A. Protective effect of Terminalia muelleri against carbon tetrachlorideinduced hepato- nephro toxicity in mice and characterization of its bioactive constituents. Pharm Biol 2015; 1-11. [PMID: 25894213]

[43] Lateef A, Azeez MA, Asafa TB, et al. Biogenic synthesis of silver nanoparticles using pod extract of Cola nitida: antibacterial, antioxidant activities and application as additive in paint. J Taibah University Sci 2016; 10: 551-62. [http://dx.doi.org/10.1016/j.jtusci.2015.10.010]

[44] Odiyo JO, Bassey OJ, Ochieng A, Chimuka L. Coagulation efficiency of Dicerocaryum eriocarpum (DE) plant. Water SA 2017 ; 43 [http://dx.doi.org/10.4314/wsa.v43i1.01]

[45] Harborne JB. Phytochemical Methods, A Guide to Modern Techniques of Plant analysis. 2nd ed. London: Chapman and Hall 1998; pp. 54-84.

[46] Lateef A, Adeeyo AO. Green synthesis and antibacterial activities of silver nanoparticles using extracellular laccase of Lentinus edodes. Not Sci Biol 2015; 7: 405-11. [http://dx.doi.org/10.15835/nsb.7.4.9643]

[47] Ahmad I, Zaiba-Beg AZ, Mehmood Z. Antimicrobial potency of selected medicinal plants with special interest in activity against phytopathogenic fungi. Indian Vet med J 1999; 23: 299-306.

[48] Kavitha D, Shilpa PN, Devaraj SN. Antibacterial and antidiarrhoeal effects of alkaloids of Holarrhena antidysenterica WALL. Indian J Exp Biol 2004; 42(6): 589-94. [PMID: 15260110]

[49] Tarfa FD, Obodozie OO, Mshelia E, Ibrahim K, Temple VJ. Evaluation of phytochemical and antimicrobial properties of leaf extract of Tapinanthus sessilifolius (P. Beauv) van Tiegh. Indian J Exp Biol 2004; 42(3): 326-9. [PMID: 15233306]

[50] Shariff MS, Sudarshana S, Umesha P, Hariprasad S. Antimicrobial activity of Rauvolfia tetraphylla and Physalis minima leaf and callus extracts. Afr J Biotechnol 2006; 5: 946-50.

[51] Hassawi D, Kharma A. Antimicrobial activity of medicinal plants against Candida albicans. J Biol Sci 2006; 6: 104-9.

[52] Akinpelu DA, Onakoya TM. Antimicrobial activities of medicinal plants used in folklore remedies in south-western Africa. Afr J Biotechnol 2006; 5: 1078-81.

[53] Manikandan T, Neelakandan T, Usha RG. Antibacterial activity of Salicornia brachiata, a halophyte. J Phytol 2009; 1: $441-3$.

[54] Sato Y, Shibata H, Arai T, et al. Variation in synergistic activity by flavone and its related compounds on the increased susceptibility of various strains of methicillin-resistant Staphylococcus aureus to $\beta$-lactam antibiotics. Int J Antimicrob Agents 2004; 24(3): 226-33. [http://dx.doi.org/10.1016/j.ijantimicag.2004.02.028] [PMID: 15325425]

[55] Cushnie TP, Lamb AJ. Antimicrobial activity of flavonoids. Int J Antimicrob Agents 2005; 26(5): 343-56 [http://dx.doi.org/10.1016/j.ijantimicag.2005.09.002] [PMID: 16323269]

[56] Mboto CI, Eja ME, Adegoke AA, et al. Phytochemical properties and antimicrobial activities of combined effect of extracts of the leaves of Garcinia Kola, Vernonia amygdalina and honey on some medically important microorganisms. Afr J Microbiol Res 2009; 3: 557-9.

[57] Aiyegoro OA, Afolayan AJ, Okoh AI. Interactions of antibiotics and extracts of Helichrysum pedunculatum against bacteria implicated in wound infections. Folia Microbiol (Praha) 2010; 55(2): 176-80 [http://dx.doi.org/10.1007/s12223-010-0026-5] [PMID: 20490761]

[58] Adwan K, Abu-Hasan N. Gentamicin resistance in clinical strains of Enterobacteriaceae associated with reduced gentamicin uptake. Folia Microbiol (Praha) 1998; 43(4): 438-40. [http://dx.doi.org/10.1007/BF02818588] [PMID: 9821296]

[59] Esimone CO, Iroha IR, Ibezim EC, Okeh CO, Okpana EM. In vitro evaluation of the interaction between tea extracts and penicillin G against Staphylococcus aureus. Afr J Biotechnol 2006; 5: 1082-6.

[60] Chuang PH, Lee CW, Chou JY, Murugan M, Shieh BJ, Chen HM. Anti-fungal activity of crude extracts and essential oil of Moringa oleifera Lam. Bioresour Technol 2007; 98(1): 232-6. [http://dx.doi.org/10.1016/j.biortech.2005.11.003] [PMID: 16406607]

[61] Zasloff M. Antimicrobial peptides of multicellular organisms. Nature 2002; 415(6870): 389-95. [http://dx.doi.org/10.1038/415389a] [PMID: 11807545] 
[62] Dahot MU. Antimicrobial activity of small protein of Moringa oleifera leaves. J Islam Acad Sci 1998; 11: 27-32.

[63] Burkill HM. The useful plants of West Africa. 92 ${ }^{\text {nd }}$ ed. Kew: Families A-D, Royal Botanical Gardens 1985; pp. 101-20.

[64] Dalsgaard A, Reichert P, Mortensen HF, Sandström A, Kofoed P-E, Larsen JL. Application of lime (Citrus aurantifolia) juice to drinking water and food as a cholera-preventive measure. J Food Prot 1997; 60: 1329-33. [http://dx.doi.org/10.4315/0362-028X-60.11.1329]

[65] Hindi NK, Chabuck ZA. Antimicrobial activity of different aqueous lemon extracts. J Appl Pharm Sci 2013; 3: 074-8.

[66] Jahn SA. Traditional water clarification methods using scientific observation to maximise efficiency. Waterlines 1984; 2: 27-8. [http://dx.doi.org/10.3362/0262-8104.1984.010]

[67] Kebreab AG. Moringa seed and Pumice as alternative natural materials for drinking water treatment, PhD thesis, KTH, Sweden, ISRNKTHLWR/Phd 1013-SE 2004. 2004; 156.

[68] Pintore G, Usai M, Juliano C, et al. Chemical composition and antimicrobial activity of Rosmarinus officinalis L. oils from Sardina and Corsica. Flavour Fragrance J 2002; 17: 15-9. [http://dx.doi.org/10.1002/ffj.1022]

[69] Wilkinson JM, Hipwell M, Ryan T, Cavanagh HM. Bioactivity of Backhousia citriodora: Antibacterial and antifungal activity. J Agric Food Chem 2003; 51(1): 76-81 [http://dx.doi.org/10.1021/jf0258003] [PMID: 12502388]

[70] Andresen M, Cedergreen N. Plant growth is stimulated by tea-seed extract: A new natural growth regulator. HortSci 2010; 45: 1848-53.

[71] Norrie J, Keathley JP. Benefits of Escophyllum nodusum marine plant extract application to 'Thompson seedless' grape production. Acta Hort $2006 ; 243-50$

[72] Yongabi KA. The role of medicinal plants in environmental biotechnology and integrated Biosystems E-seminar Proceedings of International Organisation for Biotechnology and Bioengineering. 8-22.

[73] Rassami W, Soonwera M. In vitro pediculicidal activity of herbal shampoo base on Thai local plants against head louse (Pediculus humanus capitis De Geer). Parasitol Res 2013; 112(4): 1411-6.

[http://dx.doi.org/10.1007/s00436-013-3292-8] [PMID: 23334727]

[74] Korankye O. Extraction and application of plant dyes to serve as colourants for food and textiles. 2010.

[75] Bagavan A, Rahuman AA, Kamaraj C, et al. Contact and fumigant toxicity of hexane flower bud extract of Syzygium aromaticum and its compounds against Pediculus humanus capitis (Phthiraptera: Pediculidae). Parasitol Res 2011; 109(5): 1329-40. [http://dx.doi.org/10.1007/s00436-011-2425-1] [PMID: 21541752]

[76] Olaitan AF, Abiodun AT. Comparative toxicity of botanical and synthetic insecticides against major field insects pests of cowpea (Vigna unquiculata (L) Walp). J Nat Prod Plant Resour 2011; 1: 86-95.

[77] Singha S, Adhikari U, Chandra G. Smoke repellency and mosquito larvicidal potentiality of Mesua ferra L. leaf extract against filarial vector Culex quinquefasciatus Say. Asian Pac J Trop Biomed 2011; 1: S119-23. [http://dx.doi.org/10.1016/S2221-1691(11)60137-8]

[78] Pritchard M, Mkandawire T, Edmondson A, O’Neill JG, Kululanga G. Potential of using plant extracts for purification of shallow well water in Malawi. Phys Chem Earth 2009; 34: 799-805. [http://dx.doi.org/10.1016/j.pce.2009.07.001]

(c) 2018 Adeeyo et al.

This is an open access article distributed under the terms of the Creative Commons Attribution 4.0 International Public License (CC-BY 4.0), a copy of which is available at: (https://creativecommons.org/licenses/by/4.0/legalcode). This license permits unrestricted use, distribution, and reproduction in any medium, provided the original author and source are credited. 